\title{
Amazon false cedar: a substitute for medium-density timbers from vulnerable species
}

Some Amazon timber species, such as Cedrela odorata and Swietenia macrophylla, are considered vulnerable due to overexploitation. Cedrelinga cateniformis, known as false cedar, has a medium-density wood that may replace species under great commercial pressure. We have assessed some physical (basic and apparent density; tangential, radial, and volumetric shrinkage) and mechanical properties (resistance to parallel compression, shear, static bending, and static bending stiffness), as well as the shear strength in the bonding surface. With an average apparent density of $0.721 \mathrm{~g} / \mathrm{cm}^{3}$, the C. cateniformis wood presented density and shrinkage classified as medium and anisotropy coefficient of 1,654. The mechanical properties were similar or superior to higher density woods. C. cateniformis fits the $\mathrm{C} 20$ resistance class, with the potential to substitute species such as Couratari oblongifolia, Vochysia maxima, Cedrela odorata, and Swietenia macrophylla. The shear strength in the bonding surface was lower than that of solid wood and the wood failure percentage was below the recommended. However, the results indicate that it is possible to find an efficient bond when evaluating different bond pressures. C. cateniformis have also a high potential for timber plantations, due to its ecological characteristics, for instance, resistance against the Meliacea shoot borer and association with mycorrhiza.

Keywords: Technological properties; Bonding; Meliaceae; Cedrorana.

\section{Cedro falso da Amazônia: um substituto para madeiras de densidade média de espécies vulneráveis}

\begin{abstract}
Algumas espécies madeireiras da Amazônia, como Cedrela odorata e Swietenia macrophylla, são consideradas vulneráveis devido à superexploração. Cedrelinga cateniformis, conhecido como falso cedro, possui uma madeira de densidade média que pode substituir espécies sob grande pressão comercial. Avaliamos algumas propriedades físicas (densidade básica e aparente; retração tangencial, radial e volumétrica) e mecânicas (resistência à compressão paralela, cisalhamento, flexão estática e rigidez de flexão estática), bem como a resistência ao cisalhamento na superfície de ligação. Com densidade aparente média de $0,721 \mathrm{~g} / \mathrm{cm}^{3}$, a madeira de C. cateniformis apresentou densidade e retração classificadas como médias e coeficiente de anisotropia de 1.654. As propriedades mecânicas foram semelhantes ou superiores às madeiras de maior densidade. C. cateniformis se enquadra na classe de resistência C20, com potencial para substituir espécies como Couratari oblongifolia, Vochysia maxima, Cedrela odorata e Swietenia macrophylla. A resistência ao cisalhamento na superfície de colagem foi inferior à da madeira maciça e o percentual de ruptura da madeira abaixo do recomendado. No entanto, os resultados indicam que é possível encontrar uma colagem eficiente ao avaliar diferentes pressões de colagem. C. cateniformis também apresenta alto potencial para plantações madeireiras, devido às suas características ecológicas, por exemplo, resistência à broca Meliacea e associação com micorriza.
\end{abstract}

Palavras-chave: Propriedades tecnológicas; União; Meliaceae; Cedrorana.

Topic: Ciências Florestais

Reviewed anonymously in the process of blind peer.
Received: 06/03/2021

Approved: 22/03/2021
Danielle das Flores de Sales (iD

Universidade Federal do Oeste do Pará, Brasil

http://lattes.cnpq.br/1010553882260221

http://orcid.org/0000-0002-7650-5043

dannyflores245@gmail.com

Bruno Monteiro Balboni (D)

Universidade de São Paulo, Brasil

http://lattes.cnpq.br/4885362022915207

http://orcid.org/0000-0003-1617-5254

bruno.balboni@usp.br

Alessandra Silva Batista (iD

Universidade de São Paulo, Brasil

http://lattes.cnpq.br/1281057231768001

http://orcid.org/0000-0003-4227-7801

alessandrabatista@usp.br

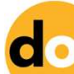

DOI: 10.6008/CBPC2179-6858.2021.003.0003
Victor Hugo Pereira Moutinho (iD

Universidade Federal do Oeste do Pará, Brasil

http://lattes.cnpq.br/8464600937488553

http://orcid.org/0000-0001-7770-3087

victor.moutinho@ufopa.edu.br

\section{Referencing this:}

SALES, D. F.; BALBONI, B. M.; BATISTA, A. S.; MOUTINHO, V. H. P. Amazon false cedar: a substitute for medium-density timbers from vulnerable species. Revista Ibero Americana de Ciências Ambientais, v.12, n.3, p.29-37, 2021. DOI: http://doi.org/10.6008/CBPC21796858.2021 .003 .0003 


\section{INTRODUCTION}

Despite the wide variety of tree species in the Amazon Forest, only a small number of these are traded as timber (MOUTINHO et al., 2011), which results in considerable ecological pressure on them (BARBOSA et al., 2010; REIS et al., 2019). The recommendation of lesser-known woods to replace those of greater exploitation is possible through the evaluation of their physical and mechanical properties (Reis et al., 2019; NASCIMENTO et al., 1997; LOBÃO et al., 2011).

In general, studies aim mainly to replace species with higher density wood (ARAÚJO et al., 2020; COSTA et al., 2012; MOREIRA et al., 2019; BALBONI et al., 2018), due to their expressive commercial value. However, there are lower wood density species with high added value, such as Brazilian cedars Cedrela odorata and Cedrela fissilis (MOTTA et al., 2014; FERNANDES et al., 2018), which are considered vulnerable due to their excessive logging (BARSTOW, 2018). From the same family (Meliaceae), the Brazilian mahogany (Swietenia macrophylla) also has medium density wood (LANGBOUR et al., 2011) and is considered a vulnerable species due to its logging.

There is, however, within the great Amazonian biodiversity, a species which similarity to cedars has earned it the name 'Cedrorana' (false cedar, in local indigenous language). This species, Cedrelinga cateniformis, occurs throughout the Amazon forest (HAAG et al., 2020), including experimental planting fields (HIGUC, 1981; MAGALHÃES et al., 2000).

When compared to Cedrela sp., Cedrelinga cateniformis has several silvicultural advantages. As it belongs to the Fabaceae family, it is not susceptible to the mahogany shoot borer Hypsipyla grandella (PEÑARAMÍREZ et al., 2011), and it is associated with nitrifying bacteria (MAGALHÃES et al., 1984). Although its wood presents interesting characteristics, good mechanical resistance (GONÇALVES et al., 2001; DIAS et al., 2004), dimensional stability (FERNANDES et al., 2018) and durability (HAAG et al., 2020), C. cateniformis has little market recognition.

Higher density wood tends to present bonding problems, due to its low porosity, high extractive contents and low dimensional stability (VICK, 1999). Unlike high-density wood species, Cedrorana has the potential to compose engineered products, such as glued laminated wood and cross-laminated wood. Glued products are a trend in the timber industry, as they allow the construction of large structures with smaller pieces and the removal of wood defects (MIOTTO et al., 2010), which can be a great additional stimulus for the use of Cedrorana wood.

In this study we evaluated the potential of $C$. cateniformis wood to replace commercial Amazonian species of medium density and compose engineered wood products.

\section{MATERIALS AND METHODS}

Cedrorana wood (C. cateniformis) was acquired through institutional partners of the Federal University of Western Pará - UFOPA. The species was identified in the laboratory through wood anatomy analysis, comparing it with samples from the wood collection of former SUDAM (Superintendence of Amazon 
Development), now in the custody of the UFOPA Wood Technology Laboratory.

The ASTM D143 standard (ASTM INTERNATIONAL, 2008) was used to determine the physical properties (shrinkage, density and anisotropy coefficient) and the mechanical properties (compression parallel to the fibers, shear and static bending). The mechanical tests were conducted in a universal testing machine with a capacity of $300 \mathrm{kN}$. Fifteen samples represented $C$. cateniformis wood in each evaluated property: shear, parallel compression and static bending strength, as well as stiffness on static bending.

The characteristic value in the compression parallel to the fibers test $(f c 0, k)$ was calculated according to the NBR7190 standard (ABNT, 1997) and classified into one of the resistance classes proposed by it. The relationship between properties obtained, was compared to the

The bond strength was assessed according to the ASTM D905 standard (ASTM INTERNATIONAL, 2008). The bonding was carried out with a commercial one-component polyurethane adhesive, following the manufacturer's guidelines (grammage of $200 \mathrm{~g} \cdot \mathrm{m}^{2}$ and bonding pressure of $0.7 \mathrm{MPa}$ ). In addition to the shear strength in the bonding surface, the proportional area in which the shear rupture occurred in the wood was calculated.

Descriptive statistics was used to analyze the evaluated variables for $C$. cateniformis wood. The comparison of shear strength in solid and glued wood was carried out by the T test as data presented normal distribution, assessed by graphical comparison between the observed and theoretical quantiles. All statistical analysis and graphs plotting were performed with software R (R DEVELOPMENT CORE TEAM).

\section{RESULTS E DISCUSSION}

\section{Physical properties}

Cedrelinga cateniformis showed a mean value of 0.567 for basic density (table 1), $20.6 \%$ higher than that found by Gonçalvez et al. (2001) and 28.9\% higher than that described by IBAMA (1997). The apparent density at $12 \%$ moisture content also followed the same trend and was higher than that reported in the literature (IBAMA, 1997; GONÇALEZ et al., 2001; DIAS et al., 2004). Despite the higher density, the radial, tangential and volumetric shrinkage were $4.8 \%, 7.9 \%$ and $11.8 \%$, respectively, similar to the values found by IBAMA (1997). However, the radial and tangential shrinkage were higher to those described by Dias et al. (2004)

Table 1: Cedrelinga cateniformis physical properties

\begin{tabular}{lllllll}
\hline & $\boldsymbol{\rho}_{\text {bas }}\left(\mathbf{g} \cdot \mathbf{c m}^{-\mathbf{3}}\right)$ & $\boldsymbol{\rho}_{\mathbf{1 2} \%}\left(\mathbf{g} \cdot \mathbf{c m}^{-\mathbf{3}}\right)$ & $\boldsymbol{\varepsilon}_{\boldsymbol{R}}(\mathbf{\%})$ & $\boldsymbol{\varepsilon}_{\boldsymbol{T}}(\mathbf{\%})$ & $\boldsymbol{\varepsilon}_{V}(\boldsymbol{\%})$ & $\boldsymbol{A C}$ \\
\hline mean & 0.567 & 0.712 & 5.013 & 8.114 & 10.864 & 1.654 \\
median & 0.604 & 0.728 & 4.8 & 8.414 & 10.978 & 1.713 \\
maximum & 0.64 & 0.799 & 6.275 & 9.962 & 11.7 & 2.35 \\
minimum & 0.462 & 0.552 & 3.629 & 5.534 & 9.644 & 1.085 \\
CV (\%) & 6.883 & 6.931 & 13.922 & 11.882 & 5.035 & 19.683 \\
SD & 0.039 & 0.049 & 0.698 & 0.964 & 0.547 & 0.325 \\
\hline
\end{tabular}

$\boldsymbol{\varepsilon}_{\boldsymbol{R}}$ : Radial Shrinkage; $\boldsymbol{\varepsilon}_{T}$ : Tangential Shrinkage; $\boldsymbol{\varepsilon}_{\boldsymbol{V}}$ : Volumetric Shrinkage; $\boldsymbol{A C}$ : Anisotropy Coefficient; $\boldsymbol{\rho}_{\text {bas }}$ : Basic density; $\boldsymbol{\rho}_{12} \%$ : Apparent density at $12 \%$ moisture content; CV: coefficient of variation; SD: standard deviation

The anisotropy coefficient is directly related to the timber quality. The value found in this study was 
similar to that described in IBAMA (1997), but differed from Fernandes et al. (2018), who reported an anisotropy coefficient of 1.31 , and Dias et al. (2004), who reported an anisotropy coefficient of 1.83 . The ideal value for the anisotropy coefficient is 1 , indicating that there is no difference in shrinkage in the tangential and radial directions (MORESCHI, 2012). This only occurs in theory and the cited author reports that woods with anisotropy coefficients between 1.6 and 1.9 are classified as normal woods, which includes Cedrelinga cateniformis.

\section{Mechanical properties}

The values found in the mechanical tests (Table 2) were similar to those described by Dias et al. (2004), but they are different from those described by Gonçalez et al. (2001), who found higher values for $E_{M O}(11.73 \mathrm{GPa})$ and $\mathrm{f}_{\mathrm{M}}(96.53 \mathrm{MPa})$.

Table 2: Cedrelinga cateniformis mechanical properties

\begin{tabular}{lllll}
\hline & $f_{\mathrm{co}}(\mathbf{M P a})$ & $\mathrm{f}_{\mathbf{M}}(\mathbf{M P a})$ & $\boldsymbol{E}_{\mathbf{M O}}(\mathbf{G P a})$ & $\mathbf{f}_{\mathbf{v 0}}(\mathbf{M P a})$ \\
\hline mean & 45.23 & 75.84 & 9.841 & 11.91 \\
median & 44.18 & 71.33 & 10.120 & 11.95 \\
maximum & 55.37 & 105.4 & 12.430 & 13.20 \\
minimum & 34.41 & 56.85 & 7.100 & 10.16 \\
CV $(\%)$ & 13.74 & 22.7 & 18.24 & 7.29 \\
SD & 6.21 & 17.21 & 1.795 & 0.869 \\
\hline
\end{tabular}

$f_{\mathrm{c} 0}$ : resistance to compression parallel to the fiber, $f_{M}$ : resistance to static bending, $\boldsymbol{E}_{\mathbf{M} 0}$ : static bending stiffness, $f_{\mathrm{v} 0}$ : resistance to shear

C. cateniformis wood density was higher than that reported in the literature. As the density of the wood has a positive influence on its mechanical properties (ZHANG, 1997; MISSANJO et al., 2016) it was expected that this wood would also show greater strength and stiffness. However, lower density Cedrorana wood (DIAS et al., 2004; GONÇALVES et al., 2001) showed similar or superior mechanical properties. This result may be associated with the extractive content, which positively influences the density, but may affect differently the wood mechanical properties (ARGANBRIGHT, 1971; PANSHIN et al., 1980; GARCIA et al., 1993). Another possible influence is the characteristics of juvenile wood, which make woods of the same density less resistant (KNAPIC et al., 2018; BALBONI et al., 2020). Mechanical properties can also be influenced by genetic factors, since the wood used in this study is from a native forest, with high variability of competitiveness, soil, water availability, among others.

The discrepancy in the relationship between mechanical properties and density may also be associated with grain orientation, since $C$. cateniformis may present intercrossed grain (GONÇALEZ et al., 2001), as confirmed by this study, what can influence positively or negatively the wood shear strenght (HERNANDEZ et al., 2003).

\section{Simplified characterization}

The $f_{v 0} / f_{c 0}$ ratio observed was $0.31,158 \%$ higher than the value indicated $(0.12)$ by the NBR 7190 standard (ABNT, 1997). The same occurred for the $E_{M_{0}} / E_{c 0}$ ratio, with a value of $1.68,86 \%$ higher than the proposed by the cited standard (0.90). 
Tests of compression perpendicular to the wood grain were not performed. Thus, through the $f_{c 90} / f_{c 0}$ ratio, the estimated value for $f_{c 90}$ was $11.30 \mathrm{MPa}$, considerably higher (3.2 times) than that found in the literature, 3.6 MPa (IBAMA, 1997).

The relations analyzed in the Brazilian standard were not representative for $C$. cateniformis, a behavior similar to those described by Sales et al. (2018) for 49 Amazonian species. According to the authors, the divergence is expected due to the wide variety of woods and their different characteristics. Therefore, caution must be adopted when using these relationships between properties, since, while overestimated projections of a given property result in excessive use of material, underestimated ones may generate risks for the structural use of wood.

\section{Characteristic Value and Resistance Class}

The characteristic value in parallel compression $\left(f_{c 0, k}\right)$ was $24.75 \mathrm{MPa}$, what fits $C$. cateniformis in the resistance class C20 (ABNT 1997), the same found by Dias et al. (2004). Knowing the resistance class facilitates the use of combined species, since they are grouped by properties similarity. Species such as Simarouba amara (JESUS et al., 2015), Erisma uncinatum, Cedrela sp, Cedrela odorata (SALES, 2004) and Schizolobium amazonicum (ALMEIDA et al., 2013) are also classified in the C20 resistance class and could all be replaced by or combined with C. cateniformis.

\section{Bonding}

The shear strength of glued samples $(9.50 \mathrm{MPa})$ was $79.8 \%$ of the value observed for solid wood (11.91 MPa). The bonding not only affected the average, but also led to an increase in the data variation (Figure 1). Obviously, high variation values are not desirable since they decrease the predictability of the wood's behavior and hinder its adoption.

The average percentage of wood failure was low (31.49\%), below the $60 \%$ recommended for nonstructural products (ASTM INTERNATIONAL, 2005). When observing the shear strength in the bonding surface in view of the percentage of wood failure, it is noticed that they are not related (Figure 2). However, with the increase in wood failure, there is a clear reduction in the shear strength variation.

The five samples that showed wood failure above $80 \%$ did not belong to the same group of samples, therefore these high values are not associated with the wood characteristic. Tracking the samples, it was found that they were at the same position in the press during bonding. Although it was not possible to determine what caused this major failure in the wood, these data provide a direction for $C$. cateniformis bonding. It is possible to reach an adequate percentage of wood failure when evaluating different bonding pressures. High values in wood failure will certainly lead to less variation in bond strength and an average closer to that observed in solid wood. This will bring greater possibilities for $C$. cateniformis wood use, both in non-structural products and in engineered wood products, a worldwide trend in the wood industry (MIOTTO et al., 2010). 


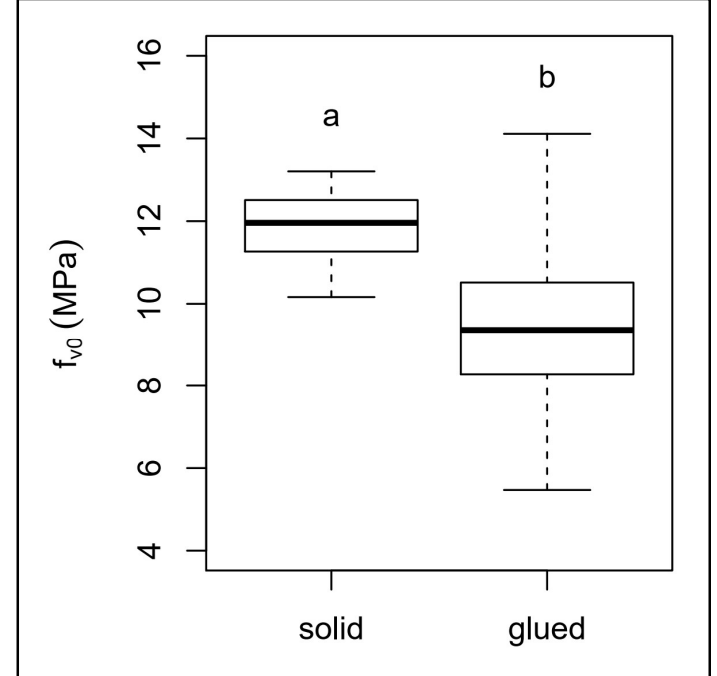

Figure 1: Shear strength parallel to fibers in solid and glued wood samples.

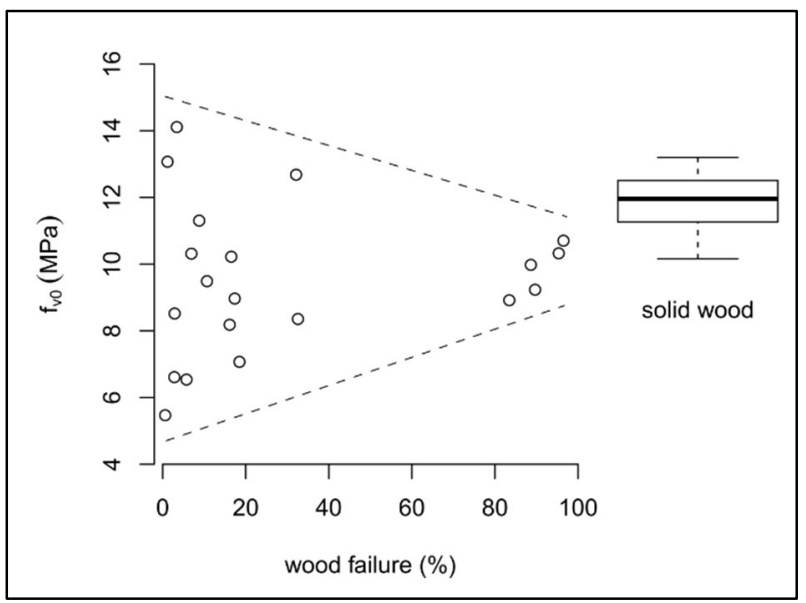

Figure 2: Shear strength of glued samples in relation to the percentage of wood failure. The boxplot represents the data from solid wood samples. Dashed lines indicate the decrease of variance on shear strength as the wood failure increases.

\section{Uses for false cedar wood}

C. cateniformis wood has properties closer to mahogany species than to cedar species, especially density, with cedars having the lowest densities (Table 3). Despite having slightly higher shrinkage, the anisotropy coefficients are in the same order of magnitude as the S. macrophylla and the two species of Khaya spp.. The timbers with from native forests, C. odorata and S. macrophylla, showed a higher mechanical efficiency (resistance/density or stiffness/density) than those from planted forests. They are superior to $C$. cateniformis mechanical properties, even though they have lower wood density. Despite this, the values are not disparate and indicate the possibility of using Cedrorana wood to replace C. odorata and S. macrophylla, species that are considered vulnerable precisely because of their intense logging.

Table 3: Wood properties from cedar and mahogany species from different origins

\begin{tabular}{|c|c|c|c|c|c|c|c|}
\hline Species & $\begin{array}{l}\rho_{\text {bas }} \\
\left(\mathrm{g} \mathrm{cm}^{-3}\right)\end{array}$ & $\begin{array}{l}\varepsilon_{R} \\
(\%)\end{array}$ & $\begin{array}{l}\varepsilon_{T} \\
(\%)\end{array}$ & A.C. & $\begin{array}{l}f_{c o} \\
(\mathrm{MPa})\end{array}$ & $\begin{array}{l}f_{M} \\
\text { (MPa) }\end{array}$ & $\begin{array}{l}E_{M O} \\
\text { (GPa) }\end{array}$ \\
\hline Cedrela odorata ${ }^{1}$ & 0.39 & 9.06 & 12.1 & 1.34 & 54.59 & 78.37 & 10.10 \\
\hline Swietenia macrophylla ${ }^{2}$ & $0.61 *$ & 2.50 & 3.50 & 1.40 & 55.10 & 88.30 & 10.96 \\
\hline Khaya ivorensis ${ }^{3}$ & 0.49 & 3.39 & 5.58 & 1.65 & 43.10 & 78.40 & 9.58 \\
\hline Khaya senegalensis ${ }^{3}$ & 0.59 & 3.11 & 5.57 & 1.79 & 46.10 & 83.20 & 10.17 \\
\hline Toona ciliata ${ }^{4}$ & 0.33 & 3.29 & 7.13 & 2.22 & 26.33 & 50.81 & 6.75 \\
\hline
\end{tabular}

* density at $12 \%$ moisture content

${ }^{1}$ SFB (2020); ${ }^{2}$ Langbour et al. (2011); ${ }^{3}$ França et al. (2015); ${ }^{4}$ Trianoski et al. (2011).

Efforts to replace the mentioned native species have been made towards the introduction of exotic species, such as the Australian cedar, Toona sp. (PAULINO et al., 2015) and the African mahogany, Khaya sp. (REIS et al., 2019). While the former presented less dense wood and lower mechanical properties, Khaya sp. is quite like Cedrorana.

These exotic species of the genera Toona and Khaya were selected to replace Brazilian cedar and mahogany because they are from the same botanical family (Meliaceae) and consequently have similar wood. One of the problems reported for the cultivation of Cedrela sp. and Swietenia sp. is the mahogany shoot borer Hypsipyla grandella, a moth which larvae damages the apical bud of these species (PAUL et al., 
2013), causing the main trunk to bifurcate, which devalues the wood. There are also reports of $H$. grandela attacks on Khaya sp. (ZANETTI et al., 2017) and the preference for oviposition in Toona ciliata rather than in the Brazilian mahogany (COSTA et al., 2000). Because Cedrorana belongs to another botanical family (Fabaceae), it is not, and hardly will be in the future, a host to the mahogany shoot borer, a great silvicultural advantage of $C$. cateniformis in relation to exotic cedars and mahogany.

Another important advantage of species from the Fabaceae family is their association with nitrifying bacteria, what allows them to develop in poor soils (MAGALHÃES et al., 1984). The authors also reported that the association of Cedrorana with mycorrhizae promotes a high rooting rate, even in unfavorable soil conditions. These characteristics are strong evidence that, in addition to providing wood through sustainable logging of native forests as a replacement for vulnerable species, $C$. cateniformes also has the potential to be used in commercial plantations.

Besides Cedrela sp. and Swietenia sp., Cedrorana can replace other woods as well, such as tauari, Couratari oblongifolia, quaruba, Vochysia maximum (IBAMA, 1997) since it has similar mechanical properties. These species are used in light external and internal, structural and decorative civil construction, and utilities in general. Regardless of the substitution of other established wood species, C. cateniformis is always pointed out in the literature as a high-quality wood that could be used externally due to its high durability (HAAG et al., 2020).

Due to its properties, especially the physical ones, the studied species has potential to be used in the industry of engineered wood products. Although it was not possible to identify the best procedure for an appropriate bonding in this study, it generated subsidies for specific studies in the future.

In addition to wood bonding, we suggest that the properties of Cedrorana wood from plantations to be evaluated, mainly from short cutting cycles, since this is a trend in tropical forestry.

\section{CONCLUSIONS}

Cedrelinga cateniformis wood was considered as medium density, medium shrinkage and classified as normal wood by its anisotropy coefficient. The mechanical properties were slightly lower than those reported in the literature for the same species. The relationships between mechanical properties proposed by the NBR7190 standard were not representative for $C$. cateniformis. The shear strength in bonding surface and the proportion of wood failure did not present satisfactory results. However, the data indicated that it is possible to find an appropriate adhesion when evaluating different pressures during bonding. Cedrelinga cateniformis was fit in class $\mathrm{C20}$, with potential to be used for the same purposes as species such as Couratari oblongifolia, Vochysia maximum, Cedrela odorata and Swietenia macrophylla.

\section{REFERENCES}

ALMEIDA, D. H. D.; SCALIANTE, R. D. M.; MACEDO, L. B. D.; MACÊDO, A. N.; DIAS, A. A.; CHRISTOFORO, A. L.; CALIL JUNIOR, C.. Caracterização completa da madeira da espécie amazônica Paricá (Schizolobium amazonicum HERB) em peças de dimensões estruturais. Revista Árvore, Viçosa, v.37, n.6, p.1175-1181, 2013. DOI: https://doi.org/10.1590/S0100-67622013000600019

ARAÚJO, A. J. C.; BALBONI, B. M.; MOUTINHO, V. H. P.. Physical and Mechanical Characterization of Astronium 
Lecointei and Manilkara Huberi Branch Wood. Floresta e Ambiente, Seropédica, v.27, n.2, 2020. DOI: https://doi.org/10.1590/2179-8087.046817

ARGANBRIGHT, D. G.. Influence of extractives on bending strength of Redwood (Sequoia sempervirens). Wood and Fiber, v.2, n.1, p. 367-372, 1971.

ABNT. ASSOCIAÇÃO BRASILEIRA DE NORMAS TÉCNICAS. NBR 7190: Projeto de Estruturas de Madeira. Rio de Janeiro, 1997.

ASTM INTERNATIONAL. American Society for Testing and Materials. ASTM D 5751: Adhesives used for laminate joints in nonstructural lumber products. Pennsylvania: ASTM, 2005.

ASTM INTERNATIONAL. American Society for Testing and Materials. ASTM D 905: Standard Test Method for Strength Properties of Adhesive Bonds in Shear by Compression Loading. Pennsylvania: ASTM, 2008.

BALBONI, B. M.; SILVA, T. S.; ANDRADE, F. W.; FREITAS, L. J; MOUTINHO, V. H. P.. Physical-mechanical characterization of two amazon woods coming from the second cutting cycle. Anais da Academia Brasileira de Ciências, Rio de Janeiro, v.90, n.4, p.3565-3572, 2018. DOI: https://doi.org/10.1590/0001-3765201820170845

BALBONI, B. M.; BATISTA, A. S.; RODRIGUES, R. A.; GARCIA, J. N.. Relationship between strength and density in juvenile and mature Eucalyptus sp. wood. Revista Brasileira de Pesquisa Animal e Ambiental, Curitiba, v.3, n.3, p.983-991, 2020. DOI: https://doi.org/10.34188/bjaerv3n3-019

BARBOSA, A. P.; VIANEZ, B. F.; VAREJÃO, M. D. J.; ABREU, R. L. S. D.. Considerações sobre o perfil tecnológico do setor madeireiro na Amazônia Central. Parcerias estratégicas, v.6, n.12, p.42-61, 2010.

BARSTOW, M.. Cedrela fissilis. The IUCN Red List of Threatened Species 2018: e.T33928A68080477. 2018. DOI: https://dx.doi.org/10.2305/IUCN.UK.20181.RLTS.T33928A68080477.en

COSTA, M. S. S.; OHASHI, O. S.; SILVA, J. N. M.; SILVA, M. D. F.. Controle da broca do mogno através da preferência de ovoposição de Hypsipyla grandella Zeller sobre Toona ciliafa M. J. Roem. plantado em consórcio com Swietenia macrophylla King. Embrapa Amazônia Oriental. Comunicado técnico, Belém, n.47, p.1-3, 2000.

COSTA, C.; MOUTINHO, V. H. P.; OLIVEIRA, M. L.; SANTOS, S. L. K. V.; SOUZA, M. R.. Caracterização físico-mecânica de madeiras amazônicas com aptidão tecnológica para comercialização. Revista de Ciências Agrárias Amazonian Journal of Agricultural and Environmental Sciences, v.55, n.3, p.176-183, 2012. DOI:

http://doi.editoracubo.com.br/10.4322/rca.2012.053

DIAS, F. M.; LAHR, F. A. R.. Estimativa de propriedades de resistência e rigidez da madeira através da densidade aparente. Scientia Forestalis, v.65, n.2, p.102-113, 2004.

FERNANDES, N. C. L.; VALLE, M. L. A.; CALDERON, C. M. A.. Características Físicas e Anatômicas de Cedrela odorata L. e Cedrelinga cateniformis Ducke. Floresta e Ambiente,
Seropédica, v.25, n.1, 2018. DOI:

http://dx.doi.org/10.1590/2179-8087.100814

FRANCA, T. S. F. A.; ARANTES, M. D. C.; PAES, J. B.; VIDAURRE, G. B; SILVA, O. J. T.; BARAÚNA, E. E. P.. Características anatômicas e propriedades físico-mecânicas das madeiras de duas espécies de mogno africano. Cerne, Lavras, v.21, n.4, p.633-640, 2015.

DOI: https://doi.org/10.1590/01047760201521041877

GARCIA, J. N.; QUIRINO, W. F.. Influência dos extrativos solúveis em água na resistência à compressão paralela da madeira de ipê (Tabebuia sp.). In: CONGRESSO FLORESTAL PANAMERICANO, 1; CONGRESSO FLORESTAL BRASILEIRO, 7 Anais. São Paulo: SBS/SBEF, 1993.

GONÇALEZ, J. C.; GONÇALVES, M. D.. Valorização de duas espécies de madeira Cedrelinga catenaeformis e Enterolobium shomburgkii para a indústria madeireira. Revista Brasil Florestal, Brasília, n.70, p.69-74, 2001.

HAAG, V.; KOCH, G.; MELCHER, E.; WELLING, J.. Characterization of the wood properties of Cedrelinga cateniformis as substitute for timbers used for window manufacturing and outdoor applications. Maderas. Ciencia y Tecnología, Concepción, v.22, n.1, p.23-36, 2020. DOI: http://dx.doi.org/10.4067/S0718-221X2020005000103

HERNANDEZ, R. E.; ALMEIDA, G.. Effects of wood density and interlocked grain on the shear strength of three Amazonian tropical hardwoods. Wood and Fiber Science, v.35, n.2, p.154-166, 2007

HIGUCHI, N. A.. Silvicultura no INPA. Acta Amazonica, Manaus, v.11, n.1, p.99-107, 1981.

IBAMA. Madeiras tropicais brasileiras: Brazilian tropical woods. Brasília: Laboratorio de Produtos Florestais, 1997.

JESUS, J. M. H.; LOGSDON, N. B.; FINGER, Z.. Classes de resistência de algumas madeiras de Mato Grosso. E\&S Engineering and Science, v.3, n.1, p.35-42, 2015. DOI: https://doi.org/10.18607/ES201532552

KNAPIC, S.; GRAHN, T.; LUNDQVIST, S.; PEREIRA, H.. Juvenile Wood Characterization of Eucalyptus botryoides and $E$. maculata by using SilviScan. BioResources, v.13, n.2, p.23422355, 2018. DOI:

https://doi.org/10.15376/biores.13.2.2342-2355

LANGBOUR, P.; GÉRARD, J.; RODA, J. M.; FAUZI, P. A.; GUIBAL, D.. Comparison of wood properties of planted bigleaf mahogany (Swietenia macrophylla) in Martinique Island with naturally grown mahogany from Brazil, Mexico and Peru. Journal of Tropical Forest Science, v.23, n.3, p.252259, 2011.

LOBÃO, M. S.; CASTRO, V. D.; RANGEL, A.; SARTO, C.; TOMAZELLO FILHO, M.; SILVA JUNIOR, F. D.; BERMUDEZ, M. A. R. C.. Agrupamento de espécies florestais por análises univariadas e multivariadas das características anatômica, física e química das suas madeiras. Scientia Forestalis, Piracicaba, v.39, n.92, p.469-477, 2011.

MAGALHÃES, L. M. S.; BLUM, W. E. H.. Nodulação e crescimento de Cedrelinga catenaeformis Ducke em plantios experimentais na região de Manaus - AM. Pesquisa 
Agropecuária Brasileira, Brasília, v.19, n.13, p.159-164, 1984.

MAGALHÃES, L. M. S.; BLUM, W. E. H.. Distribuição radicular de espécies florestais plantadas na região de Manaus, Amazônia. Floresta e Ambiente, v.7, p.93-103, 2012.

MIOTTO, J. L.; DIAS, A. A.. Produção e avaliação de vigas de madeira laminada colada confeccionadas com lâminas de eucalipto. Revista Tecnológica, p.37-47, 2009. DOI: https://doi.org/10.4025/revtecnol.v0i0.8714

MISSANJO, E.; MATSUMURA, J.. Wood Density and Mechanical Properties of Pinuskesiya Royle ex Gordon in Malawi. Forests, v.7, n.7, p.135, 2016. DOI: https://doi.org/10.3390/f7070135

MOREIRA, L. S.; MOUTINHO, V. H.. Densidade básica e resistência mecânica de madeiras de resíduos florestais da região amazônica. Revista Agroecossistemas, v.10, n.2, p.64-81, 2018. DOI:

http://dx.doi.org/10.18542/ragros.v10i2.5160

MORESCHI, J. C.. Propriedades da madeira. 4 ed. Curitiba: UFPR, 2012.

MOTTA, J. P.; OLIVEIRA, J. T. D. S.; BRAZ, R. L.; DUARTE, A. P. C.; ALVES, R. C.. Caracterização da madeira de quatro espécies florestais. Ciência Rural, Santa Maria, v.44, n.12, p.2186-2192, 2014. DOI: https://doi.org/10.1590/0103$8478 \mathrm{cr} 20130479$

MOUTINHO, V. H. P.; COUTO, A. M.; LIMA, J. T.; AGUIAR, O. J. R.; NOGUEIRA, M. O. G.. Energetic characterization of Matá-Matá wood from the Brazilian rainforest (Eschweilera Mart Ex Dc). Scientia Forestalis, Piracicaba, v.39, n.92, p.457-461, 2011. DOI:

http://doi.editoracubo.com.br/10.4322/rca.2012.044

NASCIMENTO, C. C.; GARCIA, J. N.; DIÁZ, M. D. P.. Agrupamento de espécies madeireiras da Amazônia em função da densidade básica e propriedades mecânicas. Madera y Bosques, v.3, n.1, p.33-52, 1997. DOI: https://doi.org/10.21829/myb.1997.311378

PANSHIN, A. J.; ZEEUW, C.. Textbook of wood technology. 4 ed. McGraw-Hill: New York, 1980.

PAUL, C.; WEBER, M.. Intercropping Cedrela odorata with shrubby crop species to reduce infestation with Hypsipyla grandella and improve the quality of timber. International Scholarly Research Notices Forestry, v.2013, p.1-10. 2013. DOI: https://doi.org/10.1155/2013/637410

PAULINO, D. N.; CULLEN JUNIOR, L.; BELTRAME, T. P.; OLIVEIRA, E. B.. Rentabilidade econômica de cedroaustraliano em plantios puros e consorciados com café. Colombo: Embrapa Florestas Documentos, 2015.
PEÑA-RAMÍREZ, Y. J.; GARCÍA-SHESEÑA, I.; HERNÁNDEZESPINOZA, A.; DOMÍNGUEZ-HERNÁNDEZ, A.; BARREDOPOOL, F. A.; GONZÁLEZ-RODRÍGUEZ, J. A.; ROBERT, M. L.. Induction of somatic embryogenesis and plant regeneration in the tropical timber tree Spanish red cedar [Cedrela odorata L. (Meliaceae)]. Plant Cell, Tissue and Organ Culture (PCTOC), v.105, n.2, p.203-209, 2011. DOI: https://doi.org/10.1007/s11240-010-9853-y

PEREZ, J.; EIGENBRODE, S. D.; HILE, L.; TRIPEPI, R. R.; AGUILAR, M. E.; MESEN, F.. Use of grafiting to prevent Hypsipyla grandella (Zeller) (Lepidoptera: Pyralidade) damage to new world Meliaceae especies. Neotropical Entomology, Londrina, v.39, n.4, p.618-625, 2010. DOI: https://doi.org/10.1590/S1519-566X2010000400024

REIS, C. F.; OLIVEIRA, E. B.; SANTOS, A. M.. Mogno-africano (Khaya spp.): atualidades e perspectivas do cultivo no Brasil. Brasília: Embrapa, 2019.

REIS, P. C. M. D. R.; REIS, L. P.; SOUZA, A. L. D.; CARVALHO, A. M. M. L.; MAZZEI, L.; REIS, A. R. S.; TORRES, C. M. M. E.. Agrupamento de espécies madeireiras da Amazônia com base em propriedades físicas e mecânicas. Ciência Florestal, Santa Maria, v.29, n.1, p.336-346, 2019. DOI: https://doi.org/10.5902/1980509828114

SALES, A.. Sistema de classes de resistência para dicotiledôneas: revisão da NBR 190/97. Madeira: arquitetura e engenharia, v.5, n.13, 2004.

SALES, D. F.; BALBONI, B. M.. Relação entre propriedades mecânicas de 49 madeiras Amazônicas. In: SIMPÓSIO FLORESTAL SUL-MATO-GROSSENSE, 5. Anais. Campo Grande, 2018.

SFB. Serviço Florestal Brasileiro - Laboratório de Produtos Florestais. Database of Brazilian Woods. Brasília: SFB, 2020.

TRIANOSKI, R.; MATOS, J.; IWAKIRI, S.. Propriedades físicas, químicas e mecânicas da madeira de cedro australiano cultivado em Corupá, SC. Pesquisa Florestal Brasileira, v.34 n.80, p.435-441, 2014. DOI: https://doi.org/10.4336/2014.pfb.34.80.523

VICK, C. B.. Adhesive Bonding of Wood Materials. In: Wood handbook: wood as an engineering material. Madison: USDA Forest Service, Forest Products Laboratory; General technical report FPL; GTR-113, 1999.

ZANETTI, R.; ABREU, C. S.; SILVEIRA, S. H. P.; ANDRADE, E. D.. First report of Hypsipyla grandella (Lepidoptera: Pyralidae) on African mahogany Khaya ivorensis. Scientia Agricola. Piracicaba, v.74, n.6, p.492-494, 2017. DOI: https://doi.org/10.1590/1678-992x-2016-0362

ZHANG, S. Y.. Wood specific gravity-mechanical property relationship at species level. Wood Science and Technology, Heidelberg, v.31, n.3, p.181-191, 1997.

A CBPC - Companhia Brasileira de Produção Científica (CNPJ: 11.221.422/0001-03) detém os direitos materiais desta publicação. Os direitos referem-se à publicação do trabalho em qualquer parte do mundo, incluindo os direitos às renovações, expansões e disseminações da contribuição, bem como outros direitos subsidiários. Todos os trabalhos publicados eletronicamente poderão posteriormente ser publicados em coletâneas impressas sob coordenação da Sustenere Publishing, da Companhia Brasileira de Produção Científica e seus parceiros autorizados. Os (as) autores (as) preservam os direitos autorais, mas não têm permissão para a publicação da contribuição em outro meio, impresso ou digital, em português ou em tradução. 